\title{
An Imagined Diaspora: The Making of Shi' Muslim EthNicity IN SRI LANKa
}

\author{
Harun Rasiah
}

California State University, East Bay

\begin{abstract}
The contemporary formation of a community of Shi'i Muslims provides a window into the making and unmaking of ethnicity in Sri Lanka. Originating in solidarity with the Islamic revolution of Iran, Sunni activists formed a political network which has evolved into an autonomous Shi'i religious community. Members studied the traditional Islamic disciplines in the institution of learning (hawza 'ilmiyya) in Qom alongside students who had undergone a similar transformation, fortifying an internationalist outlook. With associates in the Indian Ocean region, particularly the Gulf states, the transregional community is bound by the common thread of Shi' ism and focuses on Iran and the "Atabat of Iraq as spiritual homeland. Exploring the "diasporic consciousness" of the community, this article focuses on the transmission of ideas in time and space. Temporally, it emphasizes claims to local Muslim heritage in variant readings of the Sri Lankan past. Spatially, their cartography provides an alternative account of the sacred landscape based on scholarly practice, devotional activity and political contestation. By recounting the history and mapping the geography of the Shi'i Muslim community, this article investigates how Shi'ism influences the configuration of a diasporic field.
\end{abstract}

\section{INTRODUCTION: DiASPORIC FIELDS}

This article provides a snapshot of a larger project on the formation of a Shi'i Muslim community and the circulation of ideas in a subregion of the Indian Ocean arena, focusing primarily on Iran, Sri Lanka and Tamil Nadu. The community in Sri Lanka, with perhaps no more than 2000 members, is more significant than the story the numbers tell. With members in government, civil society and the broader Muslim community, Shi'i Muslims exert influence in a variety of activities. Like other small communities of ithna 'ashari (Twelver) Shia, they have connections to similar groups and individuals in other locations 
through the hawza 'ilmiyya in Qom, where community leaders studied. The project observes contestations of Islamic knowledge through field research on four separate visits to Sri Lanka from 2012 to 2019. The approach is interdisciplinary, using interviews, analysis of written materials, ethnographic techniques, and primary sources.

This overview considers the place of minority ithna 'ashari (Twelver) Shi' $i$ Muslims in the "diasporic field" that intersects with the nation state of Sri Lanka. ${ }^{1}$ Building on Bourdieu's concept of the political field, Brun and Van Hear conceive of the "diasporic political field" as a contested site in which capital is mobilized outside the local political field, but together form a third "transnational political field." This conception is adapted here to translocal and transregional religious fields, in which different values are articulated and reworked. Connections to the "Middle East," primarily Iran and the Gulf states, reflect the transregional aspect. Tamil Nadu, and to a much lesser extent affiliates from other nearby locations such as the Maldives, form a translocal religious field defined by linguistic and cultural affinities. The titular "imagined diaspora" combines the concepts of diasporic field with Benedict Anderson's "imagined communities" for utility in understanding a group that defies classification. ${ }^{2}$ The Shia of Sri Lanka are not an ethnicity, nation, diaspora, or even a sect in the common usage. While shaped by the state, it attempts to move beyond the nation-state model and is better viewed in terms of the translocal and transregional rather than the transnational given limited numbers and geographic scope. A survey of the diasporic field is followed by a discussion of Shi'i engagements with notions of diaspora in the circulation of ideas and through contacts with refugees and transregional connections. While Dutch and British colonialism enabled the formation of Malay Muslim and Indian Tamil diasporas respectively, postcolonial Sinhala nationalism produced the Ceylon Tamil diaspora and has targeted Muslims since the end of the civil war in 2009. The emergent Shia increasingly work with Muslim refugees from outside the country, exhibiting a diasporic consciousness based on transnational identity and religious belonging.

Centuries of European colonialism (1505-1948) in Ceylon formalized religious and ethnic divisions, refined in British policies of "divide and rule" and embedded in governmental structures. Colonial and postcolonial waves of migration created layers of diaspora within and beyond the country's borders, triggered by ethnic conflict, political

\footnotetext{
${ }^{1}$ For the concept of diasporic field see Cathrine Brun and Nicholas Van Hear, "Between the local and the diasporic: The shifting centre of gravity in war-torn Sri Lanka's transnational politics," Contemporary South Asia, 20, 1 (2012), 61-75. ${ }^{2}$ Benedict Anderson, Imagined Communities: Reflections on the origin and spread of nationalism (London: Verso, 2016), 44.
} 
instability, and economic hardship. As an ethnocracy, Sri Lanka has absorbed Sinhala Buddhist discourses of supremacy into mainstream thought and institutionalized violence through registered organizations and electoral parties like Bodu Bala Sena (BBS) and Jathika Hela Urumaya (JHU). ${ }^{3}$ In Sinhala nationalist discourse any non-Sinhala person is cast as an "immigrant," with the exception of indigenous Veddas (Wanniyalaeto), appropriated for nationalist claims or discursively relegated to extinction. As articulated by Buddhist clergy and politicians, Sinhala nationalist ideology - used here to encompass racism, nativism, and populism - infiltrates the public sphere and is weaponized by the state and social movements to influence elections, mobilize soldiers, and incite mob violence.

The first parliamentary act of the newly independent state, the Ceylon Citizenship Act of 1948, deprived citizenship to the descendants of indentured laborers known as Indian Tamils. By 1986 up to a quarter of the population had been repatriated to India. Brought to work on tea estates in the nineteenth and early twentieth century, Indian Tamils (Malaiyaha, Hill Country, Upcountry, "estate" or "plantation" Tamils) are part of the indentured Indian Tamil diaspora, and a subset of the indentured Indian diaspora of the Indian, Pacific, and Atlantic Oceans. ${ }^{4}$ With their disenfranchisement, the postcolony inaugurated political independence as a new era of divide and rule, perpetuating colonial processes after the formal end of British administration. While Nira Wickramasinghe has carefully shown how an aggregate "colonial modernity" overdetermines Sri Lankan politics and subjectivities, the assertion that state power has disproportionate effects on civilian populations still holds true. ${ }^{5}$ This is not to underestimate individual agency, but to recognize how overarching structures can take on a life of their own once enabled by individual actors. Once in motion against a minority, the juggernaut of state machinery does not easily grind to a halt. Arguably a core function of the nation state is to practice exclusion. What is a state if it cannot exercise its power to produce statelessness? A sovereignty founded on the displacement of one diaspora, Indian Tamils, would be eventually wielded against another ethnic minority to create a new diaspora, Ceylon Tamils.

\footnotetext{
${ }^{3}$ Nirmal Rajith Dewasiri, New Buddhist Extremism and the Challenges to Ethno-Religious Coexistence in Sri Lanka (Colombo: International Centre for Ethnic Studies, 2016).

${ }^{4}$ See: Hugh Tinker, A New System of Slavery: The export of Indian labour overseas, 1830-1920 (Oxford: Oxford University Press, 1974); Kay Saunders (ed.), Indentured Labour in the British Empire, 1834-1920 (London: Routledge, 1984); Ashutosh Kumar, Coolies of the Empire: Indentured Indians in the sugar colonies, 1830-1920 (Cambridge: Cambridge University Press, 2017).

${ }^{5}$ Nira Wickramasinghe, "Colonial governmentality and the political thinking through ' 1931 ' in the crown colony of Ceylon/Sri Lanka,” Socio. La nouvelle revue des sciences sociales, 5 (2015), 99-114.
} 
The literature regarding the Sri Lankan diaspora concentrates on the exodus of the Ceylon Tamil community during the civil war (1983-2009) and its aftermath. ${ }^{6}$ This group, delinked conceptually from the Indian Tamil diaspora, has been privileged in academic literature for a number of reasons. Sri Lankan or Ceylon Tamils form a traditional diasporic community that has fled state discrimination, militant authoritarianism and cycles of violence, including sporadic pogroms since 1958 and ethnic cleansing on a mass scale. It is a relatively recent development, historically speaking, and communities are accessible to researchers based in North America, Europe and Australia. Many Tamils are highly educated, speak European languages fluently and organize effectively in their new countries. Moreover, there are complexities that make the study of Tamil ethnic identity and nationalism a particularly fruitful endeavor for the study of power and identity through social movements, given the reach of the Liberation Tigers of Tamil Eelam (LTTE).

After the second phase of the civil war, the LTTE in 1990 regained control of territory from Indian peacekeepers and presided over an initiatory act of ethnic cleansing with the expulsion of an estimated 75,000 Muslims from the Northern Province. It is important to note in this regard that the concept of ethnicity in Sri Lanka has a pronounced religious basis as well as genealogical and linguistic elements. This is most salient in the category of Muslims as an ethnicity, the majority of whom were once called Moors, in contrast to ethnic Tamils. Muslim identity makes one categorically not Tamil, although both communities speak Tamil. Today Tamilnet, a news site championing selfdetermination of the Ceylon Tamils, persists in referring to them as "Tamil-Speaking Muslims." Another group of Muslims, Malays, brought during Dutch rule as workers, slaves, soldiers and exiles, are a marginalized Muslim diaspora distinct from Moors, but also intermixed with them. The contest between Tamil and Muslim leaders over the meanings of language, identity, and ethnicity thus extended into territory in the Northern and Eastern Provinces. Decades after their expulsion from the north, Muslim 'internally displaced persons' (IDPs) remain in camps in Puttalam and Kalpitiya. ${ }^{7}$ At the same time

\footnotetext{
${ }^{6}$ See: Amarnath Amarasingam, Pain, Pride, and Politics: Social movement activism and the Sri Lankan Tamil diaspora in Canada (Athens, GA: University of Georgia Press, 2015); Øivind Fuglerud, Life on the Outside: The Tamil diaspora and long distance nationalism (London: Pluto Press, 1999); Sharika Thiranagama, In My Mother's House. Civil war in Sri Lanka (Philadelphia: University of Pennsylvania, 2011).

${ }^{7}$ Sharika Thiranagama, "Shadow Diaspora," Agenda: Displacement and migration, 12 (2008), 40-42. See also: Cathrine Brun, "Hospitality: Becoming 'IDPs' and 'hosts' in protracted displacement," Journal of Refugee Studies, 23, 3 (2010), 337-355.

Abdul Razak Mohamed Imtiyaz and M.C.M. Iqbal, "The displaced northern Muslims of Sri Lanka: Special problems and the future," Journal of Asian and African Studies, 46, 4 (2011), 375-389.
} 
in the east, a series of massacres attributed to the LTTE in Kattankudy, Eravur and Palliyathidal during 1990-92 deepened the rupture between Muslims and Tamils.

Tragic events such as these contribute to Sri Lanka's position as a critical site for theorizing diaspora. The grounded perspectives of researchers who themselves have experienced displacement and exile provide insight to the discussion. For example, in the delineation of Rudhramoorthy Cheran, an influential Sri Lankan Tamil academic, poet, and activist, "all diasporas are transnational but not all transnationals are diasporas. In other words, if transnationalism is a condition of living, diaspora is about a condition of leaving. Diasporas are the result of forced migration whereas transnational communities are the result of voluntary migration." "In spite of the overstated dichotomy, this provocative definition inflects debates regarding the diasporic field in Sri Lanka. For many Tamil scholars, traumatic displacement is the defining feature of the diasporic field. The open wounds of the civil war naturally play a role in the privileging of this perspective.

Of course, there is a central place in Indian Ocean historiography for commercial diasporas that did not endure forcible removal, as well as those borne of the aforementioned labor migrations. Nonetheless, Cheran's definition demonstrates that one's positionality as a researcher influences the conceptualization of diaspora, a relationality that may foreground one collective experience at the expense of another. Some researchers, such as myself, are "second generation Tamils who visited former conflict areas in northern Sri Lanka for the first time during the 2002-04 ceasefire," a qualitatively different experience from that of refugees who escaped amidst war. ${ }^{9}$ Formation of subjectivity occurs in relation to the majority and across as well as within minority groups, yet can be remarkably nearsighted with regard to competing aspirations for self-determination. It may also heighten sensitivity to the experience of other groups, seen in the scholarly example of anthropologist Sharika Thiranagama, whose mother Rajini challenged reactionary aspects of Tamil militancy. ${ }^{10}$ Without question, ethnic Tamils have been subject to various forms of exclusion from the nation state of Sri Lanka. However, in establishing the statelet of Tamil Eelam in the traditional homeland of the

\footnotetext{
${ }^{8}$ Rudhramoorthy Cheran, "Diaspora circulation and transnationalism as agents for change in the post conflict zones of Sri Lanka" (Berlin: Berghof Foundation for Conflict Management, 2003), 4.

${ }^{9}$ Nicholas Van Hear, "Refugees, diasporas and transnationalism," The Oxford Handbook of Refugee and Forced Migration Studies, eds. Elena Fiddian-Qasmiyeh, Gil Loescher, Katy Long, and Nando Sigona (Oxford: Oxford University Press, 2014): 176-187.

${ }^{10}$ Rajan Hoole, Daya Sosasundaram, K. Sritharan, and Rajani Thiranagama, The Broken Palmyra: The Tamil crisis in Sri Lanka (Claremont, CA: Sri Lanka Studies Institute, 1992).
} 
country's North and East, the LTTE repeated the cycle of exclusion by denying Muslims a place in the formative polity. We might then ask, what is a statelet if it cannot produce 'statelet-lessness'? In instrumentalizing the power of the state or statelet against the Other, purification of the body politic, the violent displacement of minorities, premised both Sinhala and Tamil constructions of homeland. The civil war calcified boundaries around ethnic groups and religious communities, reproducing the inward nationalism that had initially precipitated separatism. Undoubtedly, Muslims have not experienced calamity on a scale comparable to human rights violations of Tamils, but given the recent history of ethnic cleansing by state and society anxieties are warranted. ${ }^{11}$ Since the end of the civil war, the requisite elements have been arrayed against Muslims and operationalized in coordinated outbreaks of violence in Dambulla in 2012, Aluthgama in 2014, Digana in 2018, and following the Easter bombings of April 21, 2019. ${ }^{12}$

Thus, the diasporic field within and beyond the national boundaries of Sri Lanka encompasses a wide typology with historical roots in various processes: commercial (Bohra, Menon, Chettiar), labor (malaiyar), ethnic (Tamil), military (Malay), and religious (Hazara, Pakistani). To these conventionally defined diasporas, we can ask what is the position of internally displaced people (IDPs) and those at risk of violence who have not been forced out of the country, but increasingly view emigration as an option? Different dimensions of migration have created a diasporic consciousness, a set of attitudes and sensibilities that is part of the political condition of being a minority in Sri Lanka. Theological difference also taps into this diasporic consciousness and inflects it with religious tropes of movement and loss. ${ }^{13}$ This article argues that by invoking historical, theological and jurisprudential arguments, the Shi'i community on the ground and through digital platforms cultivates an "imagined diaspora," one that complicates notions of diaspora just as it seeks recognition as an autonomous ethnic formation at the national level.

\footnotetext{
${ }^{11}$ For debates on how the Tamil diaspora uses the charge of genocide, see: Oliver Walton, "Framing disputes and organizational legitimation: UK-based Sri Lankan Tamil diaspora groups' use of the 'genocide' frame since 2009," Ethnic and Racial Studies, 38, 6 (2015), 959-975. Ronit Ricci explores Sarandib as refuge and place of exile with an emphasis on the Malay community in: Ronit Ricci, Banishment and Belonging: Exile and diaspora in Sarandib, Lanka and Ceylon (Cambridge: Cambridge University Press, 2019).

${ }^{12}$ See: John Holt, (ed.), Buddhist Extremists and Muslim Minorities: Religious conflict in contemporary Sri Lanka (Oxford: Oxford University Press, 2016).

${ }^{13}$ For elaboration of this concept see: Aisha Khan, "Rites and rights of passage: Seeking a diasporic consciousness," Cultural Dynamics, 19, 2-3 (2007), 141-164.
} 


\section{History: From Political Caucus to Future Ethnicity}

The community of ithna 'ashari Shi'i Muslims originated during 1979 as a political entity and evolved into a theological subgroup of Muslims. For a brief period, Iran's Islamic revolution captivated the political imagination of Sunni activists around the world. In Sri Lanka a joint subcommittee of Jamath-e Islami (JI) and the Sri Lanka Muslim Students Federation staged rallies in support of Iran and disseminated information about unfolding events. This group, the Organization to Support the Islamic Revolution of Iran (OSIRI), generated its own dynamic as an increasingly autonomous political formation. At the outset it resembled a party caucus with a focused political agenda, a mandate to advocate in support of the Islamic Revolution. However, the caucus exceeded its charge when several of its founders embraced Shi'ism. This turn was propelled by an educational process that included reading English materials from Iran and translating them into Tamil, meetings with Iranian cultural attachés, and eventually visits to the Islamic Republic for pilgrimage and extended study.

The shift from perceptions of Shi'i Islam in strictly political terms to viable theological alternative did not transpire immediately or uniformly. It is significant that intellectual curiosity, in the wider context of political commitment, drove the process of legitimating one interpretation of Islam among many. For forty years, veteran activists and newer members have rehearsed arguments to justify their beliefs, and applying reason in multiple ways have woven a social epistemology that binds the community. When members present the faith in private to extended family and trusted associates, they may highlight political issues like support for Palestine or condemnation of Saudi Arabia. They cite Qur'anic verses as evidence for the validity of Ja'fari jurisprudence as an alternative to Shafi'i fiqh. In other cases, members voice disagreement with principles of Ash'ari creed. The version of Shi'i thought to which they adhere privileges the role of demonstration in establishing proofs as sound methodology. Defending Shi'i beliefs requires basic fluency in theological, jurisprudential, and political ideas. In this way the intellectual independence that brought them into the fold of Shi' ism remains intact, but now as a matter of defense in addition to exploration. Indeed, intellectual practices are a defining feature of the community both for its own sake and to argue for one's existence, as it were. Moreover, the political and intellectual concerns that initially attracted them to Shi'ism are also exercised in internal criticism of the group and its direction. Debates continue on the merits of local and national leadership, qualifications of the maraja taqlid, rulings of various mujtahids, the relevance of wilayat al-faqih, and perceived cultural 
impositions of Arab and Persian scholars. The community is concentrated in three swathes of the country surrounding Colombo, Kandy, and Batticaloa, with significant pockets near Polonnaruwa and the southeast coast. Further afield there are contacts in the translocal area of South India and the Maldives, while other members work and study in the Persian Gulf region including Iran, Kuwait, Oman, Saudi Arabia, and the United Arab Emirates. There are a few geographic outliers in Australia, New Zealand, France, and the United States. Common theology and ethnicity link the Shi'i community, composed entirely of former Sunni Muslims, with the exceptions of a Hindu Tamil convert to Islam in France and several local Malays. Their affiliates in the Maldives and South India are nationals of those states. Almost all Sri Lankan members hail from the "Ceylon Moors," a term used for native Sunni Muslims in the first half of the twentieth century. Community members are internally differentiated by region, locality, education, social class, family status, and so forth, yet remain embedded within, and indistinguishable from, the wider population of Muslims. In this sense, the critical reassessment of literary, material and cultural heritage constitutes an engagement with their own history.

In a capsule narrative of origins, the community has connected itself to the broader umma: "It is believed that descendants of the Hashimi clan first introduced the school of Ahlul Bait (AS) to this blessed land when most of them were compelled to flee Umayyad and Abbasid atrocities against them. They sailed through Indian Ocean and settled down in this part of the world. The re-emergence of the Shia community began almost 35 years ago." 14 This fleeting yet suggestive account of their formation situates them in the longue durée of Islamic history, in which the community is linked to the lineage of the Prophet's clan, the Bani Hashim, and their partisans. This retelling suggests a diasporic origin of the island's Muslim community in escaping the early dynasties' persecution of the people of the prophetic house, ahl al-bayt. The "blessed land," makes reference to the site of Adam's earthly descent, as reported in hadith, while an evocation of Sri Lanka's description as the "resplendent isle." The group's emblem features a ship, the Bani Hashim's ark of salvation (safinat najat) against the background of Adam's Peak, with the Indian Ocean figuring as a diasporic space through which Muslims sailed. Shi'ism has experienced a local "reemergence," the revival of a dormant tradition. The metaphor of diaspora informs their self-image insofar as having unearthed a buried heritage. Rather than viewing themselves as an innovative, late twentieth-century reformist group, they consider their work to be a revitalization of original Islam, a return to roots. In this way they resemble other

${ }^{14}$ Community development plan, 24 March 2016. 
contemporary Muslim groups seeking a return to the sources of tradition. However, whereas Salafi factions disregard or attempt to efface Sri Lankan Muslim heritage in order to purify the religion from the influences of Sufism, Hinduism, and Buddhism, the Shia seek to preserve the past and reread it from another horizon, with a retrospective vision of the ahl al-bayt in mind. Embedded in local history, they speculate on the Shi'i origins of Sri Lankan Muslims as evidenced in nomenclature like the prevalence of names of the $a h l$ al-bayt, literary forms like poetry, rituals, and festivals like Mawlid and 'Ashura. This reclamation of heritage recasts Sufism and traditionalist Islam as being in harmony with Shi' $i$ notions of love for the Prophet and his family, encapsulated in the resounding benedictions (salawat) of "Allahumma salli 'alaa Muhammad wa ali Muhammad" that echoes throughout community gatherings. This project of seeking knowledge and recovering heritage forms a critical practice in the life of the community.

Sri Lankan Shia may be viewed as an ethnicity-in-formation in their demand for official recognition as a minority group to which the state must give due rights, privileges, and protections. Following violence in Valaichchenai in June 2017, an incident in which the police failed to provide security or to apprehend the perpetrators, the Eastern branch has sought legal recognition by registering as a religious organization. ${ }^{15}$ Another important factor lending toward their "ethnification" is the growing isolation of the community in terms of marriage, most pronounced in the Central Highlands. Marked as heterodox, they face serious obstacles to their reproduction and must therefore rely on intermarriage with other community members from different branches rather than through extended family and contacts. In this aspect, observance of social boundaries has created a hard division between them and their Sunni counterparts. Based on their current trajectory, it is possible that they will form a distinct ethnicity if they continue to gain adherents, reproduce through intermarriage, and consolidate their standing with the next generation. They can be identified as an emergent theological grouping whose process of identity formation parallels that of ethnicity. Ethnicity, however, may not suffice as a concept with which to theorize their characteristics. "Rather than being viewed as an ethnicity, diaspora may be alternatively considered as a framework for the study of a specific process of community formation."16 The frame of diaspora can be useful in

\footnotetext{
${ }^{15}$ Harun Rasiah, "Toward Muslim pluralism: Dialogue and discord in contemporary Sri Lanka," in Emergent Religious Pluralisms, eds. Jan-Jonathan Bock, John Fahy, and Samuel Everett (London: Palgrave Macmillan, 2019).

${ }^{16}$ Kim D. Butler, "Defining diaspora, refining a discourse," Diaspora: A journal of transnational studies, 10, 2 (2001), 189219.
} 
understanding subjects that do not yet (or may not ever) constitute an ethnicity in the textbook definition.

The official recognition in Sri Lanka of the longstanding Dawoodi Bohra community, with a common faith, heritage, and language, sets an important precedent for the Twelver Shia, whose goal is to work similarly alongside other ethnic and religious subgroups as equals. Bohra family ties and commercial networks span the world and the community exercises control over institutions without external interference. Crucially, their wealth and influence make them significant actors in the economy by financing Sunni community projects, which in turn affords them political space and social stability. The Twelver Shia aspire to be such a model community: powerful and influential, autonomous yet secure. A key difference, however, is that the self-contained Bohras do not proselytize, and therefore Salafis do not consider them a threat.

The Twelver Shia do not meet the conventional criteria for being a diaspora. They have neither been forcibly dispersed on the basis of being Shia or voluntarily migrated en masse, and have only begun to reproduce ideologically as the second generation reaches maturity. While Muslims in general have also experienced the tragedies of civil war and have been forced from their homes, they have migrated chiefly for economic reasons. Yet, having opted to follow a widely misunderstood and marginalized school of theology and law (madhhab), the Shia live on the margins and are vulnerable to persecution. Due to this position of alterity, they share many of the characteristics of a group living in an exilic state. Social expulsion resembles internal exile with an accompanying sense of alienation. In this way the broader research project interprets the making of Sri Lankan Shia in terms of potential integration, exclusion or confrontation in the three areas of the country respectively. If "diaspora must be understood as a condition of subjectivity rather than an object of analysis," then it can be a useful frame for understanding their positionality within the Muslim community and the greater polity, as well as the international sphere of Shi' ism in Sunni contexts. ${ }^{17}$

\section{DEGREeS OF DANGER}

As an imagined diaspora, Twelver Shi'a overlap with members of actual diasporic communities. In this way they are also privy to articulations of diaspora by co-religionists in flight from sectarian violence. Headquartered in the capital, the main branch of the community provides services such as receiving refugees and Shi'i asylum seekers from

\footnotetext{
${ }^{17}$ Lily Cho, "The turn to diaspora," Topia: Canadian journal of cultural studies, 17 (2007), 11-30.
} 
Afghanistan and Pakistan. The leadership has contracted with the United Nations High Commissioner for Refugees (UNHCR) to help resettle migrants at risk for their religious beliefs in their home countries. In Afghanistan and Pakistan, Hazaras have been racialized as having "Asiatic" features that allow them to be identified visibly as Shia. Refusing to abide by international conventions, the Sri Lankan state is not a signatory of the 1951 Refugee Convention and has itself been accused of crimes against humanity. Moreover, the government has violated the principle of non-refoulement, returning refugees and asylum seekers to their home countries. Added to the uncertainty of their political status, international refugees are conspicuous and during anti-Muslim violence have faced attacks from Sinhala nationalists. Having survived the Taliban and life in the shadow of armed factions like Lashkar-e Jhangvi and Ahle Sunnat Wal Jamat (formerly Sipah-e Sahaba) in Pakistan, migrants encounter rising Buddhist extremism in an ostensible safe haven. Buddhist clergy and their supporters have openly supported the Burmese junta and staged violent demonstrations against the presence of Rohingya refugees from Myanmar, in spite of being temporarily settled in Sri Lanka. ${ }^{18}$

Sharing Twelver Shi'i beliefs, Pakistani and Hazara migrants have been absorbed into the community in the Western Province and attend religious programs with local members. In the ethos of modern Shi'ism, the virtuous ideal is to embrace refugees, exiles, dissidents, and travelers. The Imams themselves experienced exile and imprisonment, and Imam Husayn is considered the archetypal "stranger among strangers" (gharib alghuraba), martyred in a distant land. According to the supplication of 'Arafa recited on Hajj, he is said to have lamented, "I complain to You about my alienation (ghurbati) and my foreignness ( $b u$ 'da dari)." In the metahistory of the ahl al-bayt's persecution, affective elements of exile and solitude infuse the mourning ceremonies (majalis), rites of visitation (ziyara), and supplications at the heart of religious life. In the contemporary scene, migrants have risked their lives journeying to Sri Lanka and religious programs provide a way of assimilating them into the local community while strengthening social ties among themselves as they discuss news from home, future directions and the status of their individual cases.

For the leadership of the Shi'i community based in Colombo, this relatively new development has meant making adjustments such as opening the doors to newcomers while maintaining secrecy so as not to create tensions with Sunni Muslims. Hosting refugees involves interfacing with governmental, NGO and international bureaucracies.

18 "UNHCR alarmed at violence against Rohingyas in Sri Lanka," Reuters (27 September 2017). 
The activities of translation, preparing documents, attending interviews, and writing reports take place under the auspices of the Shi'i organization, although limited to those proficient in Persian and English and with civil service and legal experience. The community's senior leader and foremost scholar, fluent in Persian after years of study in Iran, has not only worked for the UN, but translated at the highest levels of diplomatic talks between the government and the Islamic Republic of Iran. Other civil servants who studied in Iran use their knowledge of Persian as an advantage for communication with refugees on an informal basis.

The combined force of Sinhala nationalism and Sunni reformism exerts pressure on the Shia and, in conjunction with limited economic opportunities, contributes to emigration. The Salafi drive to eradicate innovation (bid'a) has influenced the intellectual environment in which all Muslim groups articulate ideas. Condemnation of polytheism in Friday sermons overtly targets Sufi orders and the Shia. On the counterattack, Sunni traditionalists accuse "Wahhabis," as Salafis are labeled, of destroying Muslim material and literary heritage. On a greater scale, Sinhala nationalists have deployed the specter of "Wahhabism" to implicate all Muslims. The Shi'i community has worked with traditionalists to resist the Salafist tendency, which has made inroads into mainstream Sunni organizations like the All Ceylon Jamiyyathul Ulema (ACJU). ${ }^{19}$ With the current campaign against Muslim extremism and radicalization after the Easter bombings, antiWahhabi sentiment has reached a fever pitch. Within the Muslim community, there is soul searching about Wahhabism in Sri Lanka and Muslim intellectuals have become increasingly critical of its origins. ${ }^{20}$ Respected journalist and author, Latheef Farook, writing in the Colombo Telegraph, offers a view on the geopolitics of Sunni reformism: "It is well known that after the oil boom, US-Israeli controlled Saudi spent billions of dollars exporting Wahhabi Islam to counter the rise of Imam Khomeini and to show that Saudi is the leader of Muslims." 21 This stream of analysis from a Sunni intellectual, like that which the community circulates online, locates the proliferation of Wahhabism in a broader political economy of sectarianism and counter-sectarianism. With the rise of Salafi and Wahhabi discourses, Shia that remain enculturated in Sunni contexts have resorted to a number of strategies to ensure their security. Inhabiting a Shafi'i frame of reference, it is possible for Shia to view themselves through the lens of Sunnism and

\footnotetext{
${ }^{19}$ Ameer Ali, "Kattankudy needs new leadership and direction,” Daily Financial Times, (14 May 2019). See also: Dennis B. McGilvray, "A matrilineal Sufi Shaykh in Sri Lanka," South Asian History and Culture, 5, 2 (2014), $246-261$.

${ }^{20}$ See: Hamid Algar, Wahhabism: A critical essay (Oneonta, NY: Islamic Publications International, 2002).

${ }^{21}$ Latheef Farook, "Re-election of Rizvi Moulavi as ACJU president; reflects religious \& moral bankruptcy of Muslim community," Colombo Telegraph (23 July 2019).
} 
combat misconceptions. The practice of dissimulation (taqiyya) provides flexibility to share beliefs in situations that are not life threatening or compromise the group's security. Added to the dangers inherent in being a Shi'i Muslim in a changing political climate are the vulnerabilities of refugees and asylum seekers.

\section{ETHICS AND FIQH OF MigRATION}

Interactions among scholarly members of the community highlight the ways in which religious ideas are debated, in part based on individual positionality and prospects for the future. In the following example, two former students of Qom from different backgrounds took divergent approaches to the question of permissible (mubah) action in relation to mobility and migration. The community had established a small husayniyya south of the capital in a beach town with perhaps the longest history of continuous Muslim settlement on the island. Run privately in the neighborhood of its founder, a businessman with legal training, the center hosts religious programs for a select clientele. Sayyid Husayn, the resident 'alim at the time in 2017, was a Pakistani asylum seeker who studied in Qom and earned a doctorate in Islamic philosophy from the University of Tehran. He had fled Lahore, where he was a popular speaker on the minbar, upon receiving police intelligence that his life was in danger. Stranded in Sri Lanka, he awaited the resolution of his asylum claim. The community leadership initially housed him in the Colombo headquarters and appointed him to lead prayers and religious programs.

In spite of his own precarious status, Sayyid Husayn roundly criticized another focal subject, Kareem, for having trafficked Tamil asylum seekers and Muslim migrants to Australia by ship. The scholar asserted that undertaking the hazardous journey by sea was impermissible because it endangered the lives of the passengers. Kareem, the boat owner and a fisherman by trade, was himself a former hawza student in Qom and had only resorted to smuggling migrants on one occasion in the absence of employment. He had returned from menial work in Saudi Arabia to find that the local fishing industry had been debilitated by international competition. He traveled in the North and East to recruit potential migrants, and bribed navy personnel to secure safe passage for his vessel along the coast. In his opinion the armed forces, occupying the North and with a sizeable presence in the East, turned a blind eye to emigration of Tamils and Muslims because it diluted the region's ethnic composition to favor the Sinhala majority. Sayyid Husayn, the Pakistani 'alim, saw the situation in terms of law and ethics, while economics and politics compelled Kareem, the Sri Lankan talib, to leverage the demand for emigration. He threw 
caution to the winds and had even planned to take the sea route to Australia himself in hopes of obtaining citizenship there. Moreover, he insisted, on the voyage that he had coordinated there were no fatalities, and the ship landed safely. For Kareem, having invested in GPS navigation and communication systems, the ends justified the means. While Sayyid Husayn had made great sacrifices by leaving his family and homeland behind, he envisioned a bright future for all of them under the guarantees of asylum. On the other hand, Kareem believed he had undertaken sufficient precautions to mitigate the risks in seeking a better life abroad. This debate that weighed survival and flight highlights the ethical values guiding jurisprudential thinking, under political exigency and economic pressure. While in this instance they did not cite specific texts, or formally invoke jurisprudential precedents, their disagreement reflects differing ethos and sensibilities. It also reveals how migrants of a scholarly bent view processes of mobility in which they are intimately involved and the degree to which potential dangers and rewards condition decision-making. In the end, Kareem did not profit on his venture, managed to evade authorities, and returned to fishing in Sri Lanka, while Sayyid Husayn received political asylum in the United States, where he was joined by his family and is currently the resident 'alim of a Shi'i center.

\section{SAFE House}

In late April 2019, following the Easter attacks targeting Christians and other civilians by ISIS sympathizers, the government conducted raids on Muslim establishments and residences. In Panadura, a predominantly Sinhala area 25 kilometers south of Colombo, another safe house of the Shi' $i$ community, hosting refugees, was the subject of a police operation. The town had previously witnessed anti-Muslim violence in 2014, when vigilantes firebombed an outlet of the Muslim-owned No Limit fashion chain. In the aftermath of the Easter attacks, police confiscated books, documents, cassettes, and other materials from the Shi'i center. Under new directives, security agencies unleashed a dragnet approach to policing Muslims, in which surveillance and interrogation became a national policy bordering on social practice. Kareem had been stopped on his motorbike and interrogated at police checkpoints on the A4 Batticaloa Road, the major thoroughfare along the east coast. He maintained that the controls were designated strictly for Muslims and that Tamil and Sinhala motorists passed unimpeded. Not only was the state involved, but society at large participated in examining Muslims for traces of "extremism." The close reading of religious materials for subversive content has brought increased attention 
to styles of clothing, particularly those associated with Arab culture. ${ }^{22}$ In this context of rising surveillance, the term "safe house" has the double meaning of a place of security for refugees, and as a site of hypothetical "terrorist" activity. While municipal officials in Panadura had suspended construction of the building, neighbors signed a petition against members of the congregation for "suspicious conduct of prayers in the building." 23 Refugees and asylum seekers are fearful of the anti-Muslim climate and seek resettlement elsewhere, preferably where their rights are proactively guaranteed. In an interview with Groundviews, an Afghan refugee stated that "previously people used to smile, now they view us with suspicion and hostility. This makes us fearful of travel. When I was looking to rent a room, the guest house owner shouted that 'all Muslims are terrorists'. I tried to find other guest houses, but no one is willing to accommodate." 24 The establishment in Panadura was to be the flagship institution of the Shi'i community in the Western Province, after shifting their hidden headquarters from Dehiwala, Colombo. Described as both a husayniyya and an imambarga, the new site was funded by local subscription and charitable donations. International bodies managing refugee resettlement would be expected to approve the facility as indicated by its title, a "Foundation of Muslim Refugees," in which the organization's charter has expanded to institutionalize hospitality. In a deteriorating situation for Muslims, and particularly visible refugees and asylum seekers, it remains to be seen how the Shi'i community can implement their newfound mission of serving others in Sri Lanka.

\section{DisPERSAL OF IDEAS}

To be a Shi'i Muslim in Sri Lanka is to inhabit a fluctuating state of alterity. This condition is marked by concealment (taqiyya), confinement and exclusion, but also possibility. The connection to other minority Shi'i communities, an International emerging in the "1979 moment," 25 also forms another type of network, one that is religious, political, and intellectual. In Indonesia, Malaysia, Nigeria, the Philippines, Senegal and many other places, Shi'i communities exist on the margins of Muslim societies. They are at the same time interconnected by a common experience of studying in Qom, dubbed "alumni" of

\footnotetext{
${ }^{22}$ Lisa Fuller and Rukshana Rizwie, "Muslims 'targeted with arbitrary arrests' after Easter massacre," Al-Jazeera (16 June 2019).

${ }^{23}$ Kapila Somaratne, "Panadura safe house searched,” Daily News (29 April 2019).

${ }^{24}$ Ruki Fernando, "Refugee crisis in Sri Lanka after the Easter bombings," Groundviews (4 May 2019)

25 "The 1979 Moment in the Middle East," TRAFO - Blog for transregional research:

https://trafo.hypotheses.org/category/the-1979-moment-in-the-middle-east [Accessed: 11 February 2021].
} 
the hawza 'ilmiyya or Mustafa International University (MIU est. 2007). They fear violence from the state, ethnic majorities, and other Muslim groups, complicating antagonisms and unsettling formulaic binaries. Their sense of marginality is not a culturally inherited persecution complex derived from centuries of trauma, but results from the ongoing assassination and imprisonment of Shi'i actors. My research also disputes the idea that they are "converts," as they have not rejected, as much as delimited, normative Sunnism by locating the Prophet's family at the center of their worldview. The term I use to describe this epistemic shift from the Shafi'i to Ja'fari madhhab is "reorientation," a change in theological, legal, and political direction to encompass "Alid piety." 26 "Conversion" suggests a definitive break, while "reorientation" seeks to redefine the Sunnah by including the experience of the ahl al-bayt as models that continue the prophetic example. Moreover, while the orientation for Muslims remains the qibla that faces Mecca, the range of pilgrimage sites has broadened to include Mashhad and Qom in Iran, the 'Atabat in Iraq, and Sayyida Zaynab in Damascus, Syria. ${ }^{27}$ Furthermore, enfolded within the practice of ziyara are visits to shrines of Sufi saints buried in Sri Lanka. In this way expressions of vernacular religion, such as the arduous climb to view Adam's footprint or a visit to an urban darga in Colombo, fits into the transnational devotional circuit. In this reconfiguration of sacred geography, a special status is reserved for the city of Qom, the burial place of Hazrat Fatima Ma'suma, as a site of learning and spiritual attainment. There the community found a wellspring of knowledge and guidance, as well as concrete social and organizational support, and began to crystalize into a new formation, an international network. The frame of a "diaspora for others" is useful here in that it refocuses center-periphery relations of homeland and satellite, and instead cultivates relationships with other localizations of the diaspora, providing for a holistic sense of diasporic community. ${ }^{28}$ In the disparate locations mentioned above, scholars, students, and activists engage in parallel activities of reexamining received wisdom. Thus, community building is a process of localizing, such as making claims to Muslim heritage, "translocalizing" by forging regional links, and internationalizing in the "South-South"

\footnotetext{
${ }^{26}$ Harun Rasiah, "Ideas in motion: Transmission of Shi'i knowledge in Sri Lanka," in Shia Minorities in the Contemporary World: Migration, transnationalism and multilocality, eds. Oliver Scharbrodt and Yafa Shanneik (Edinburgh: Edinburgh University Press, 2020). See also: Chiara Formichi and Michael Feener (eds.), Shi 'ism in Southeast Asia: 'Alid piety and sectarian constructions (Oxford: Oxford University Press, 2015).

${ }^{27}$ See: H. Algar, "Atabāt" in Encyclopaedia of Islam, Second Edition, eds. P. Bearman, Th. Bianquis, C.E. Bosworth, E. van Donzel, and W.P. Heinrichs (Leiden: Brill, 2012); Sophia Rose Arjana, Pilgrimage in Islam: Traditional and modern practices (London: Oneworld Publications, 2017); Edith Szanto, "Beyond the Karbala paradigm: Rethinking revolution and redemption in Twelver Shi'a mourning rituals," Journal of Shi'a Islamic Studies, 6, 1 (2013), 75-91.

${ }^{28}$ See: Iain Walker, "The Hadrami diaspora: A "diaspora for others" in the Indian Ocean," Journal of Indian Ocean World Studies, 4, 2 (2021), 188-210.
} 
terms of the global Shi'i community. In Sri Lanka Shi'i Muslims, like other ethnic and religious minorities, are suspect, and find themselves caught between proving they belong to the nation state and identifying with international visions of the umma. The dual construction of ethnicity and cultivation of diasporic consciousness validates with its internal logic a unique cultural existence interconnecting the margins.

\section{Digital Community}

The main form of communication that compensates for the physical distance separating the transnational community is the "group chat" function of the popular Whatsapp platform, owned by Facebook. Community leaders moderate several group chats that deal with current issues, including one for the inner circle and another for a mixed audience of Sunni and Shia. They are used for recitation of supplications, circulation of hadith, discussion of political concepts, and, preponderantly, news and opinion. Posted in Tamil and English, international news aligns with the community's geopolitical outlook. A participatory practice of their anti-imperialist politics is to voice resistance to the policies of the US, UK, Israel, and Saudi Arabia, an alliance that includes non-state "takfiri" proxies from al-Qaeda to Daesh. Predictably, they side with the countervailing political framework, at the vanguard of which stands the Islamic Republic of Iran. Moreover, the community expresses support for popular forces in Bahrain, the Palestinian resistance, Yemen's Houthis, and embattled Shi'i communities around the world, particularly Shaykh Ibrahim Zakzaky's Islamic Movement of Nigeria. In July 2014 they issued a rare public announcement by sending the imprisoned scholar condolences after the Nigerian armed forces "martyred" three of his sons and thirty others in the Quds Day commemorations of Ramadan. They use Whatsapp to forward news of his health and updates from the campaign to release him from the London-based Islamic Human Rights Commission, another key source of information. They also cite articles from movement newspapers like Crescent International that since the 1980s have maintained the rare stance of solidarity across the sectarian divide. Espousing the political line of Sunni-Shia unity (wahda), they highlight legal rulings stating the permissibility of praying behind the imam of any Friday congregation. The jurisprudence of political unity enables mobility, integration, and comradery with co-religionists at local and international levels, while using unwavering support for "the oppressed" (mustadafin) to bolster legitimacy.

While global solidarity preoccupies the group chat, the turn to digital connectivity has also had the unintended consequence of local disconnection. In spite of facilitating 
communication, the availability of information technologies has simultaneously reduced dependence on live assemblies so that members converse online in lieu of attending gatherings or meeting in person as individuals and families. Numerous factors contribute to dispersal, such as ideological differences and disagreements over community-building tactics. The senior leadership based in Colombo has taken a long view of change at the local level, and effectively ceded authority over the eastern branch, while participating in state diplomacy and nongovernmental initiatives for interethnic harmony. This 'elite' activity differs substantively from grassroots community and institution building, the modus operandi of the Central and Eastern Provinces. These two hubs still meet regularly to attend religious programs organized by branch leadership, albeit with a more localized membership than in the cosmopolitan capital. In the face of pressure, the community maintains a consistent online presence that has also come to incorporate Tamil Shia in Chennai and to establish direct contact between these communities, a newfound translocality beyond the nation state enabled by common linguistic and cultural ties. The digital assemblage of information and opinion supported by connections to the Tamil sphere of Southern India and the Middle East helps to form an "imagined diaspora," to adapt Anderson's notion of an "imagined community." The imagined diaspora has largely replaced the pivotal element of vernacular print culture with digital media to form a "unified field of exchange and communication." 29 The translation of devotional and polemical texts from Arabic or Persian into Tamil, such as the rendering of Imam Zayn al-'Abidin's Sahifa Sajjadiyya, has a broad distribution online, thanks to financial support and audiences on both sides of the Palk Strait.

By positioning Sri Lanka within a global Shi'i imaginary, the community has carved a place for itself in the sacred geography. Interconnection with the global community provides empirical strength where local numbers fall short. This inclusive narrative offers epistemic justification for its own raison d'etre. Their affirmation of similarly marginalized communities such as Bohras, Hazaras, Pakistanis, and Rohingyas also reframes Muslims as a diverse body with the effect of conferring upon the Shia legitimacy within the polity. The presence of Shi'i Muslim refugees and asylum seekers in the Western Province demands more than the consideration of hospitality, but formal recognition as official guests of the state. Moreover, it amplifies the prevailing account of the Shia as a persecuted group, a mechanism through which local Shi'i bodies may gain recognition and protection in the modern state.

\footnotetext{
${ }^{29}$ Anderson, Imagined Communities, 44.
} 
In Sri Lanka and abroad, new Shia also seek recognition from their established coreligionists of Arab and Iranian backgrounds. One of their challenges lies in being accepted on equal footing with members of traditional Shi'i communities without being racialized as "Others." It is well documented that Sri Lankans, primarily women, have migrated in large numbers to Lebanon and the Gulf states for domestic or unskilled work, where in addition to labor exploitation they occupy the lowest rungs of gender and racial hierarchies and often face physical and sexual abuse. Shi'i community members are not represented in this demographic in significant numbers; however, Kareem worked in the fast-food industry in Qatif, Saudi Arabia for two years and experienced discrimination on the basis of his ethnicity. He said it was "very dangerous to walk at night because groups of local men might beat you or throw stones or something worse," implying sexual assault. While decrying such treatment, community members remain loyal to ideals of Shi' ism, if not always its practitioners. In Sri Lanka community leaders singled out several Iranian diplomats posted in Colombo whose careerist attitudes it was felt betrayed the spirit of the revolution. "We must hold them accountable," a senior figure said. Using connections to Iran, Sri Lankan Shia made complaints to government officials of the Islamic Republic about the highhanded conduct of Colombo-based Iranians. In this way the 'periphery' holds a mirror up to the 'center'. In such outlying pockets of Shi'ism activists, having made considerable sacrifices to maintain the faith, possess an acute sense of what is at stake, perhaps overlooked by visiting members of Iran's religious, cultural, educational and political bureaucracy.

\section{Conclusion: An 'Imagined’ Diaspora}

On the margins of Sri Lanka, an ethnocratic state that has historically discriminated against minorities and yielded a global Tamil diaspora, Twelver Shi'i Muslims dwell in a zone of alternating invisibility and vulnerability. Yet, the new Shia stake claims, exercise dissimulation (taqiyya), and employ multiple strategies of assimilation, flight, and confrontation. Like many small communities they have a rich repertoire of ways of being, and engage self-reflexively in critical discussion about appropriate courses of action, quietism and intentional ambivalence. There is generational impatience with the lack of community development and younger activists from Muslim majority rural areas are not hesitant to make their presence felt. Those Shia in the Sinhala-majority Western and Central Provinces hold to a more cautious line that will not expose them to attack. Members have migrated to other nation states for economic reasons, exacerbated by social 
exclusion. They conceal their theological affinities abroad and integrate into expatriate Sri Lankan Muslim circles undetected while attending gatherings of other Shia. In the Persian Gulf region, the main destination for employment, they vigilantly maintain taqiyya among Sunni expatriates rather than face potential difficulties on return to Sri Lanka. Since digital communication spreads rumors and innuendo as rapidly as religious ideas and news, dissimulation is a preventative approach to offset the debilitating effects of isolation.

More than an ideological network, the post-1979 Shi'i International can be framed as a theological, transnational community with diasporic characteristics. ${ }^{30}$ For the hawza 'alumni' of Qom, Iran serves as spiritual homeland for its primary importance as a site of ziyara, but also as the originary site of interaction in which students and scholars forged social bonds. In the religious worldview, Sri Lankan Shia connect themselves to the flight of refugees from the first two dynasties of Islam, when Bani Hashim ostensibly crossed the Indian Ocean and alighted in Sarandib, the land of Adam. This claim has no traceable basis in ethnicity, but operates in the current view as a kind of political genealogy. The island, an auspicious site for multiple religions, figures as a historical refuge from persecution, and the community's embrace of contemporary Shi'i refugees from Afghanistan and Pakistan assimilates into this narrative. The network transcends national boundaries to create a sense of local identity and recognition of sister communities around the world, often numerically minor but culturally powerful. Beginning as a transnational intellectual network and extending into an archipelago of communities, its constituent units have faced varying degrees of repression both by the state and/or Sunni organizations wary of rivals. This common thread unifies them into a global imaginary, increasingly connected on social media, rather than through a collective reading of printed materials. From being a purely metaphorical diaspora, the community has intersected with diverse refugees, asylum seekers, and exiles, whose presence offers new perspectives which enrich the thought of the local community, while simultaneously challenging their capacity and unitary culture.

Being a Shi'i Muslim signifies membership in a community marked by religious difference that is often hidden, but modulated based on proximity and calculation. More pronounced are the features of political dissidence and intellectual autonomy, which can be leveraged to discuss religious matters. Immersed in Tamil, Arabic and Persian culture in oral, print, and digital media, the Shia in Sri Lanka and beyond function openly and clandestinely under the general category of Muslims. Factors influencing their disposition

\footnotetext{
${ }^{30}$ Chibli Mallat, The Renewal of Islamic Law Muhammad Baqer as-Sadr, Najaf and the Shi' $i$ International (Cambridge: Cambridge University Press, 1993), 7.
} 
include religious discourse and proximity to migrants, transnational connections, global patterns of political resistance, and anti-Shia violence, amidst domestic anxieties surrounding ethnic violence and religious excommunication. On this basis, the Twelver Shia of Sri Lanka exhibit what might be described as a "diasporic consciousness" without formally constituting a diaspora in any conventional sense. Nonetheless, factoring in communal bonds of solidarity and perceptions, they can be counted as one small branch of an "imagined diaspora" of Shi'i communities on the Indian Ocean littoral stretching from the Swahili coast to Indonesia. 